Original Research Article

\title{
Hyperglycaemia lowering activity and hypoglycaemic risk assessment of Sarenta, an Ivorian traditional herbal remedy
}

\author{
Geneviève A. N'guessan-Irié ${ }^{1 *}$, Ange A. Tako ${ }^{2}$, Etienne K. Effo ${ }^{1}$, \\ Landry S. Kouakou ${ }^{1}$, Gisèle N. Siransy-Kouakou ${ }^{1}$
}

\begin{abstract}
${ }^{1}$ Department of Pharmacology,
${ }^{1,2}$ Training and Research Unit of Pharmaceutical and Biological Sciences, Felix HouphouetBoigny University, Abidjan, Côte d'Ivoire
\end{abstract}

Received: 28 June 2019

Accepted: 31 July 2019

\section{*Correspondence to: \\ Dr. Geneviève A. N'guessan- Irié, \\ Email: jemigrace@gmail.com}

Copyright: (C) the author(s), publisher and licensee Medip Academy. This is an openaccess article distributed under the terms of the Creative Commons Attribution NonCommercial License, which permits unrestricted noncommercial use, distribution, and reproduction in any medium, provided the original work is properly cited.

\begin{abstract}
Background: Diabetes remains a major public health problem for which traditional medicine is a better therapeutic alternative for low-income populations, including African populations. The aim of this work was to evaluate the effect of Sarenta, an herbal preparation used in Ivorian traditional medicine as anti-diabetic, on hyperglycaemia and on basic glycaemia.

Methods: Hyperglycaemia lowering activity was led in rats receiving glucose at $5 \mathrm{~g} / \mathrm{kg}$ body weight by gavage after oral pre-treatment with either Sarenta at 125,206 or $209.5 \mathrm{mg} / \mathrm{kg}$ b. wt., either glibenclamide at $10 \mathrm{mg} / \mathrm{kg} \mathrm{b}$. wt., or physiological saline solution. Hypoglycaemic risk was assessed by administering the same doses of Sarenta to native i.e. NaCl-treated rats. For both tests, blood glucose was measured before any substance was administered and then every hour for 4 hours.

Results: After 4 hours, Sarenta at $206 \mathrm{mg} / \mathrm{kg}$ b. wt. and $209.5 \mathrm{mg} / \mathrm{kg} \mathrm{b}$. wt. significantly reduced the induced hyperglycaemia in rats by $33.87 \%$ and $37.39 \%$, respectively. The degree of the hyperglycaemia lowering effect of the remedy at these two doses was not significantly different from that of glibenclamide. In addition, Sarenta at $209.5 \mathrm{mg} / \mathrm{kg}$ b. wt. resulted in a significant reduction of basic blood sugar to $29.78 \%$ four hours after administration.

Conclusions: The remedy Sarenta has a hyperglycaemia lowering activity that could partially justify its traditional use in the treatment of diabetes. However, considering its hypoglycemic effect, precautions should be taken when using this traditional medicine.
\end{abstract}

Keywords: Plant, Diabetes, Blood glucose

\section{INTRODUCTION}

Diabetes, a metabolic condition characterized by chronic high blood sugar level, is no longer just a disease of developed and wealthy countries. ${ }^{1}$ By 2045 , more than 600 million people worldwide will have diabetes. ${ }^{2}$ In Côte d'Ivoire, the only national data available indicated a prevalence already at a level of $5.19 \% .^{3}$

Diabetes can also be a major cause of damages in the heart, vessels, eyes, kidneys and nerves. ${ }^{4}$ It is therefore essential to properly control the disease in order to significantly reduce the risk of complications.

High costs of conventional medicines for people in lowincome countries, in addition to the difficulties of access to these drugs, direct patients towards traditional remedies. Indeed, about $80 \%$ of rural populations living in developing countries depend on traditional medicine to meet their primary health needs. ${ }^{5}$ Then, the World Health Organization, recognizing the importance of traditional medicine, recommends its valuation on evidence of effectiveness, quality, and safety. ${ }^{6}$ 
Sarenta is an Ivorian traditional remedy, mainly herbal and indicated in multiple pathologies including diabetes. Several pharmacological studies undertaken by our laboratory team have highlighted safety then analgesic, antioxidant and anti-inflammatory properties without ulcerogenic risk of this remedy. ${ }^{7,8}$ The anti-diabetic activity of Sarenta does not appear to have been studied experimentally by other scientists. The present study therefore proposed to evaluate the remedy in vivo in rats blood sugar.

\section{METHODS}

\section{Extraction procedure}

The remedy Sarenta, obtained from the traditional therapist agency (Nadieco Pharma SARL), has been evaporated in a Memmert oven for 72 hours at $50^{\circ} \mathrm{C}$. The dry residue was crushed to have a fine powder of the remedy that was packaged in a bottle and kept in the refrigerator at a temperature of $5^{\circ} \mathrm{C}$ for later use. At the same time, the dosages claimed by the traditional therapist (2 tablespoons once a day i.e. $30 \mathrm{ml}, 2$ tablespoons twice a day i.e. $60 \mathrm{ml}$ and one tea glass once a day i.e. $45 \mathrm{ml}$ of the remedy) were evaporated and the dry residues allowed calculating the corresponding concentrations and then the doses to be administered to the rats, knowing that it is permissible to administrate 10 $\mathrm{ml} / \mathrm{kg}$ body weight in this way, $30 \mathrm{ml}$ of the remedy corresponded to a dose of $125 \mathrm{mg} / \mathrm{kg} \mathrm{b}$. wt., $60 \mathrm{ml}$ corresponded to $206 \mathrm{mg} / \mathrm{kg} \quad$ b. wt. and $45 \mathrm{ml}$ corresponded to $209.5 \mathrm{mg} / \mathrm{kg}$ b. wt.

\section{Pharmacological tests}

\section{Oral glucose tolerance test}

The test was carried out according to the method described by Kambouche et al. ${ }^{9}$ Healthy adult Wistar albino rats weighting between 128-179 g, under 16 hours fasting conditions, were divided into five groups of six rats. First the basic blood glucose of each rat was read using a glucometer. Then immediately, the following substances were administered to rats by gavage according to their group:

Group 1, as control, received normal saline $(\mathrm{NaCl} 0.9 \%$ at $10 \mathrm{ml} / \mathrm{kg}$ b. wt. per os).

Group 2 received standard drug (glibenclamide $10 \mathrm{mg} / \mathrm{kg}$ b. wt. per os).

Groups 3, 4, and 5 received respectively graded doses of Sarenta (105, 206 and $209.5 \mathrm{mg} / \mathrm{kg}$ b. wt. per os).

Thirty minutes later (T0) we induced hyperglycaemia by administering glucose to rats by gavage at the dose of 5 $\mathrm{g} / \mathrm{kg} \mathrm{b}$. wt.
Blood glucose was then measured at $30 \mathrm{~min}, 1 \mathrm{~h}, 2 \mathrm{~h}, 3 \mathrm{~h}$ and $4 \mathrm{~h}$ after glucose gavage in rats.

The variation in blood glucose was calculated using the following formula:

$$
\frac{G t-G 0}{G 0} \times 100
$$

G0=Blood glucose measured at $30 \mathrm{~min}$ after glucose gavage in rats.

$\mathrm{Gt}=$ Blood glucose measured at $1 \mathrm{~h}, 2 \mathrm{~h}, 3 \mathrm{~h}$ or $4 \mathrm{~h}$ after glucose gavage in rats.

\section{Hypoglycaemic risk assessment}

The test was carried out according to the method described by Puri. ${ }^{10}$ Healthy adult Wistar albino rats weighting between 128-179 g, under 16 hours fasting conditions, were divided into four groups of six rats. First the basic blood glucose of each rat was read using a glucometer. Then immediately, the following substances were administered to rats by gavage according to their group:

Group 1, as control, received normal saline $(\mathrm{NaCl} 0.9 \%$ at $10 \mathrm{ml} / \mathrm{kg} \mathrm{b}$. wt. per os);

Groups 2, 3, and 4 received respectively graded doses of Sarenta (105, 206 and $209.5 \mathrm{mg} / \mathrm{kg}$ b. wt. per os).

Blood glucose was then measured at $1 \mathrm{~h}, 2 \mathrm{~h}, 3 \mathrm{~h}$ and $4 \mathrm{~h}$ after substances administration.

The variation in blood glucose was calculated using the following formula:

$$
\frac{G t-G 0}{G 0} \times 100
$$

G0=Blood glucose measured before substances administration.

$\mathrm{Gt}=$ Blood glucose measured at $1 \mathrm{~h}, 2 \mathrm{~h}, 3 \mathrm{~h}$ or $4 \mathrm{~h}$ after substances administration.

\section{Statistical method}

Values were expressed as mean $\pm \mathrm{SD}$ (standard deviation) with $\mathrm{n}=6$ rats per group. Data were analyzed with GraphPad Prism. $7^{\circledR}$ software by Wilcoxon statistical test, with criterion set for statistical significance at $\mathrm{p}<0.05$ for risk of $\alpha=0.05$.

\section{Ethical approval}

The experimental procedures were conducted after the approval of the Ethical Guidelines of the University (Ivory Coast) Committee on Animal Resources. All these 
procedures used, were in strict accordance with the guidelines for Care and Use of Laboratory Animals and the statements of the European Union regarding the handling of experimental animals (86/609/EEC).

\section{RESULTS}

Peak hyperglycaemia occurred 1 hour after glucose administration in rats, with a higher blood glucose level in rats pre-treated with normal saline. Sarenta, at $206 \mathrm{mg} / \mathrm{kg}$
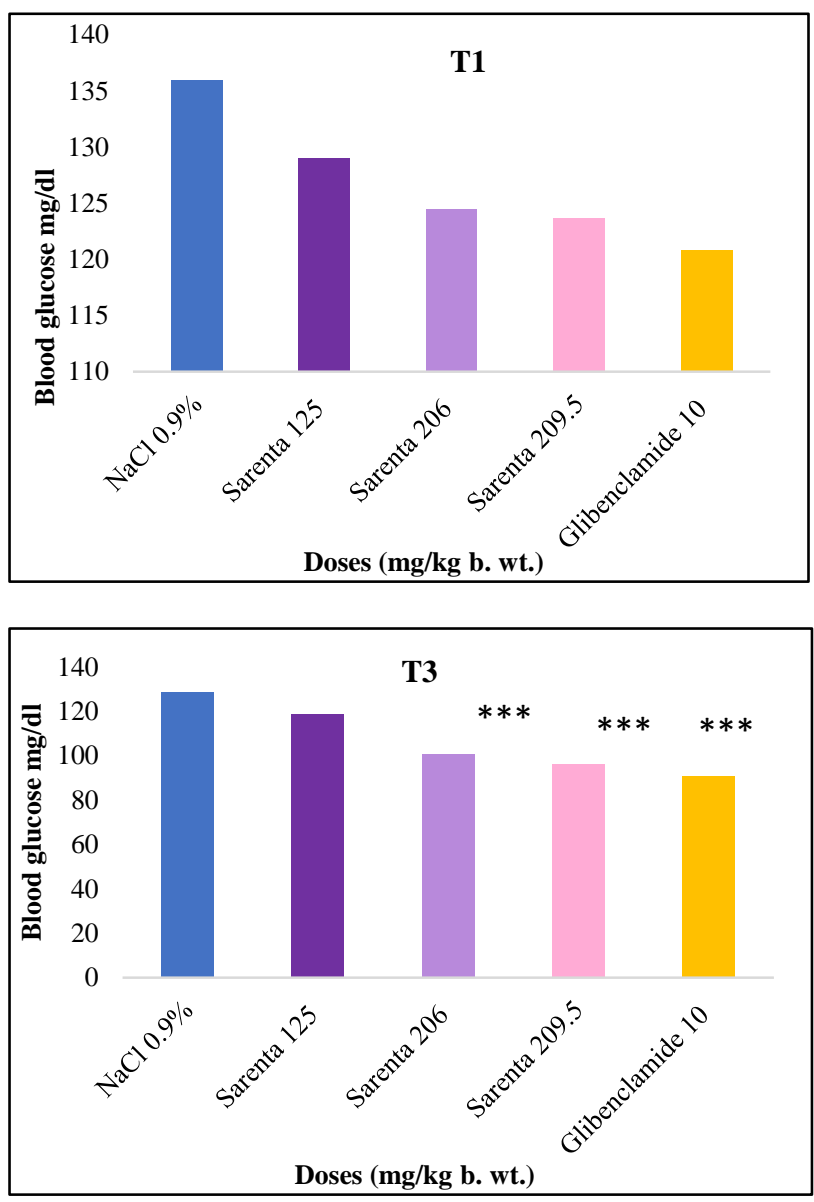

Figure 1: Blood glucose levels after oral glucose tolerance test in rats receiving Sarenta.

T1: Peak hyperglycaemia 1 hour after glucose administration; T2: Blood glucose levels 2 hours after glucose administration; T3: Blood glucose levels 3 hours after glucose administration; T4: Blood glucose levels 4 hours after glucose administration. $* 0.01<\mathrm{p} \leq 0.05 ; * * 0.001<\mathrm{p}<0.01 ; * * * \mathrm{p}<0.001$.

Table 1: Basic blood glucose in rats according to sampling times.

\begin{tabular}{|c|c|c|c|c|c|c|}
\hline \multirow{2}{*}{ Groups } & \multicolumn{6}{|c|}{ Basic blood glucose (mg/dl) } \\
\hline & T0 & $\mathrm{T} 1$ & $\mathrm{~T} 2$ & T3 & $\mathrm{T} 4$ & $P$ value \\
\hline Normal saline $\mathrm{NaCl} 0.9 \%$ & $97.83 \pm 11.14$ & $96.17 \pm 9.56$ & $93 \pm 9.94$ & $90,67 \pm 8.09$ & $88.67 \pm 10.01$ & \\
\hline Sarenta 125 mg/kg b. wt. & $89.167 \pm 9.02$ & $91.5 \pm 9.24$ & $89.67 \pm 9.24$ & $80.83 \pm 10.12$ & $74.17 \pm 12.07$ & 0.0268 \\
\hline Sarenta $206 \mathrm{mg} / \mathrm{kg}$ b. wt. & $83 \pm 11.52$ & $82 \pm 12.01$ & $80.17 \pm 13.15$ & $76.17 \pm 11.21$ & $69.83 \pm 10.45$ & 0.0004 \\
\hline Sarenta $209.5 \mathrm{mg} / \mathrm{kg}$ b. wt. & $94.5 \pm 17.05$ & $76.83 \pm 13.23$ & $73 \pm 15.36$ & $71.5 \pm 14.92$ & $66.83 \pm 9.62$ & 0.0001 \\
\hline
\end{tabular}

At the dose of $209.5 \mathrm{mg} / \mathrm{kg}$ b. wt., Sarenta resulted in a significant decrease in rat basic blood glucose to $29.78 \%$ 4 hours after administration. However, the doses of 206

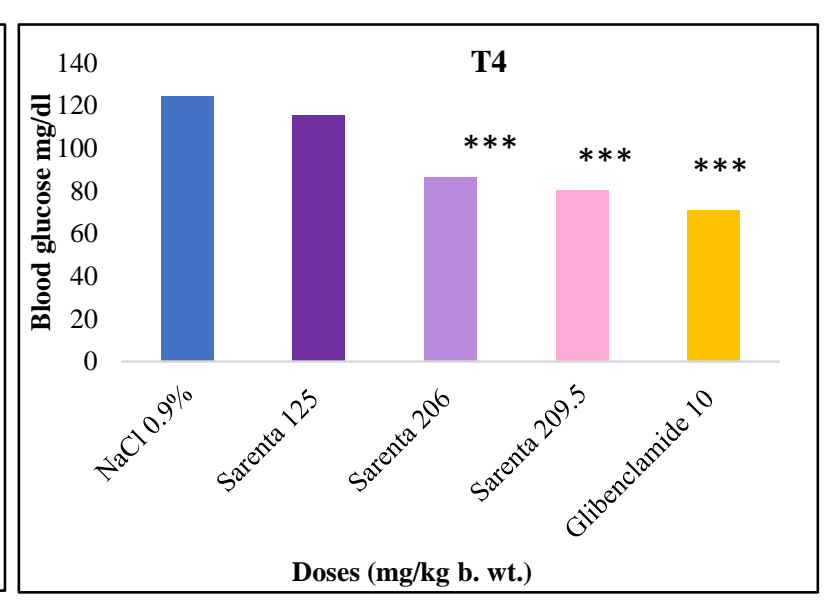

b. wt. and $209.5 \mathrm{mg} / \mathrm{kg}$ b. wt., resulted in a decrease in rat blood glucose levels 2, 3 and 4 hours after induction of hyperglycaemia. Indeed, the percentages of blood glucose reduction at these sampling times were $4.83 \%, 19.35 \%$ and $33.87 \%$ for the dose of $206 \mathrm{mg} / \mathrm{kg} \mathrm{b}$. wt. The percentages of blood glucose reduction for the dose of $209.5 \mathrm{mg} / \mathrm{kg}$ b. wt. were also $6.5 \%, 21.95 \%$ and $37.39 \%$ (Figure 1). The intensity of the hyperglycaemia lowering effect of the remedy at these two doses was superimposed on that of glibenclamide (Figure 2).

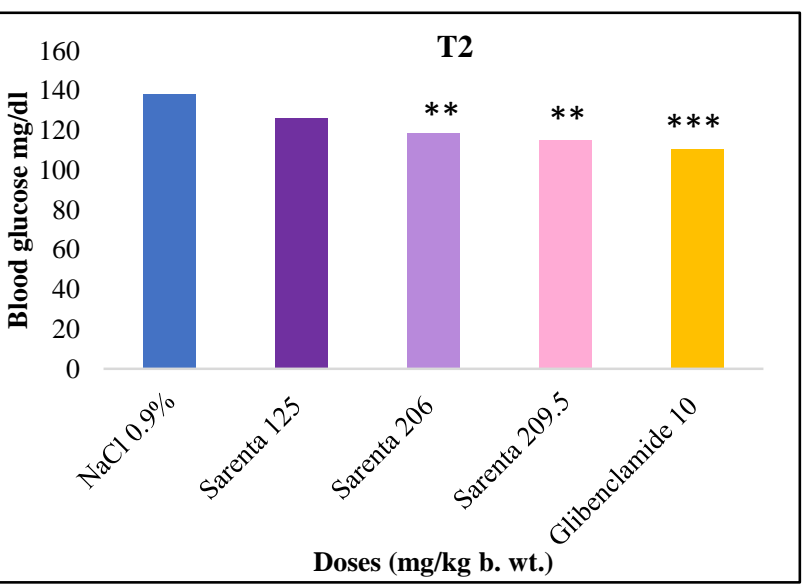




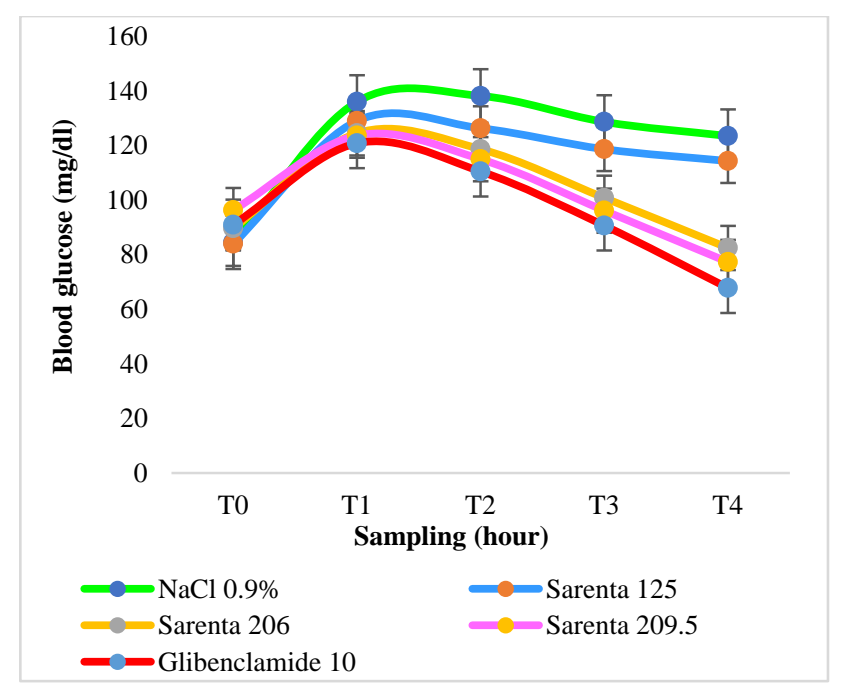

Figure 2: Decreased blood glucose under Sarenta.

\section{DISCUSSION}

The scale of diabetes worldwide, particularly in lowincome countries, calls for increased research to find new, effective and less costly therapeutic solutions. Moreover, the use of herbal medicine in the treatment of diabetes is common in Africa, as evidenced by the fact that $31 \%$ of diabetic patients hospitalized in the endocrinology department of the Hospital and University Center Mohamed in Marrakech (Morocco) made exclusive use of herbal medicine. ${ }^{11}$

Many plants including Cassia occidentalis, Moringa oleifera, Ocimum gratissimum and Tamarindus indica are known for their anti-diabetic activity. ${ }^{12-15}$ All the plants mentioned are present in the composition of Sarenta, which could explain the indication of this remedy in diabetes.

The traditional remedy Sarenta exerted a hyperglycaemia lowering action of similar intensity to that of glibenclamide which is a powerful hypoglycaemic sulfonylurea. From a mechanistic point of view, sulfonylureas have been reported experimentally to induce lower blood sugar levels in hyperglycaemic rats by stimulating the production of insulin by the beta cells of the pancreas, thereby promoting the storage of glycogen in the liver. ${ }^{16}$ further experiments may specify the type of action of the remedy at the cellular level.

Furthermore, in the absence of hyperglycaemia, Sarenta at $209.5 \mathrm{mg} / \mathrm{kg} \mathrm{b}$. wt. resulted in a significant decrease in the basic blood glucose in rats. It is well known that any extract or molecule likely to decrease blood glucose under fasting conditions of 16 hours in rats acts by inhibiting liver and kidney production of glucose, either directly or indirectly through insulin release. ${ }^{17}$ Thus, the remedy may have acted by one of these mechanisms, probably through insulin release like glibenclamide.
Finally, the dry residues obtained from the remedy were not proportional to the starting volumes so that the doses were not reproducible. Standardization of the different preparation processes would make it possible to move towards an antidiabetic plant drug.

\section{ACKNOWLEDGEMENTS}

The authors thank Nadieco Pharma SARL agency for having provided the remedy, and the Hospital and University Center of Cocody for the technical tray made them available.

\section{Funding: No funding sources}

Conflict of interest: None declared

Ethical approval: The study was approved of the Ethical Guidelines of the University (Ivory Coast) Committee on Animal Resource

\section{REFERENCES}

1. Besançon S, Sidibé AT, Nientao I. Le diabète au Mali: aspects diététiques. Développement et Santé. 2009;193:38-43.

2. International Diabetes Federation. IDF Diabetes Atlas, 8th ed. 2017.

3. International Diabetes Federation. IDF Diabetes Atlas, 6th ed. 2013.

4. Fagot-Campagna A, Romon I, Fosse S, Roudier C. Prévalence et incidence du diabète, et mortalité liée au diabète en Franc : Synthèse épidémiologique, 2010. Available at: http://opac.invs.sante.fr/ doc_num.php?explnum_id=102. Accessed on 12 March 2019.

5. World Health Organization. WHO Traditional Medicine Strategy 2002-2005, 2002. Available at: http://whqlibdoc.who.int/hq/2002/WHO_EDM_TRM _2002.1.pdf. Accessed on 23 January 2019.

6. World Health Organization. WHO Traditional Medicine Strategy 2014-2023, 2013. Available at: https://www.who.int/medicines/publications/tradition al/trm_strategy14_23. Accessed on 30 January 2019.

7. Kouakou-Siransy G, Effo KE, Irié-Nguessan G, Koua D. Analgesic efficacy, quality and safety of "Sarenta": An herbal preparation from Ivorian traditional medicine. Int J Pharmacol. 2017;13(3):257-65.

8. Effo KE, Djadji ATL, N'Guessan BN, Kouakou SL, Anzoua E, Fatto N, et al. Evaluation of the Antiinflammatory activity and ulcerogenic risk of "Sarenta", an Ivorian herbal preparation. Int J Pharm Pharmacol 2018;2(3):2581-3080.

9. Kambouche N, Merah B, Derdour A, Bellahouel S, Younos C, Soulimani R. Activité antihyperglycémiante d'un stérol $\beta$-sitoglucoside isolé de la plante Anabasis articulata (Forssk) Moq. Phytothérapie. 2011;9(1):2-6.

10. Puri D. The insulinotropic activity of a Nepalese medicinal plant Biophytum sensitivum: preliminary 
experimental study. J Ethnopharmacol. 2001;78(1):89-93.

11. Ouhdouch F, Errajraji A, Diouri A. La phytothérapie dans le traitement du diabète type 2. Diabetes Metab. 2008;34(3):99.

12. Arya S, Jogender S, Singh S. Antidiabetic activities of Cassia occidentalis. Recent Res Sci Technol. 2013;5(1):51-3.

13. Gbekley HE, Karou DS, Gnoula C, Agbodeka K, Anani K, Tchacondo T, et al. Étude ethnobotanique des plantes utilisées dans le traitement du diabète dans la médecine traditionnelle de la région maritime du Togo, Pan Afr Med J. 2018;30:186.

14. Aguiyi J, Obi C, Gang S, Igweh A. Hypoglycaemic activity of Ocimum gratissimum in rats. Fitoterapia. 2000;71(4):444-6.

15. Maiti R, Jana D, Das U, Ghosh D. Antidiabetic effect of aqueous extract of seed of Tamarindus indica in streptozotocin-induced diabetic rats. J Ethnopharmacol. 2004;92(1):85-91.

16. Gebreyohannis T, Shibeshi W, Asres K. Effects of Solvent Fractions of Caylusea abyssinica (Fresen) Fisch. \& Mey. on blood glucose levels of normoglycemic, glucose loaded and Streptozomicininduced diabetic rodents. J Nat Remedies. 2014;14:67-75.

17. Shrayyef M, Gerich J. Normal glucose homeostasis. In: Principle of Diabetes Mellitus. Springer; 2010: 19-35.

Cite this article as: N'guessan-Irié GA, Tako AA, Effo EK, Kouakou LS, Siransy-Kouakou GN.

Hyperglycaemia lowering activity and hypoglycaemic risk assessment of Sarenta, an Ivorian traditional herbal remedy. Int J Basic Clin Pharmacol 2019;8:1939-43. 